\title{
THE RELATIONSHIP BETWEEN BURNOUT AND ORGANIZATIONAL COMMITMENT WITH ROLE OF MODERATOR OF DEMOGRAPHIC VARIABLES (CASE STUDY: SOCIAL SECURITY ORGANIZATION OF WEST DEPARTMENT OF MAZANDARAN PROVINCE)
}

\author{
Somaieh Roshantalab Haghani \\ Department Of Public Management, Bandar E Anzali Branch, Islamic Azad University, Gilan, Iran \\ bordbaramn@gmail.com \\ Morteza Hazraty \\ Department Of Public Management, Bandar E Anzali Branch, Islamic Azad University, Gilan ,Iran \\ Mohammadreza Moosivand \\ Department Of Public Management, Bandar E Anzali International Branch, Islamic Azad University, \\ Gilan, Iran \\ Amir.m1234567@gmail.com
}

\begin{abstract}
The aim of the present study is to reveal the relationships between the burnout levels of the people employed insocial security organization of west department of Mazandaran province (as well as relevant subdimensions such as emotional exhaustion, depersonalization, and reduced personal accomplishment) and their levels of organizational commitment (as well as relevant sub-dimensions such as affective commitment, continuance commitment, and normative commitment). The study makes use of the following scales: "Burnout Scale" and "Organizational Commitment Scale". In this context, a brief definition of burnout would be the reaction of the individual against the demands and the stress levels of the workplace, whereas organizational commitment might be defined as the interest and the attachment of the individual towards the organization (as well as a comparative sense of belonging). As a result of the analyses carried out, the Pearson correlation coefficient (a parametric test) has been calculated in order to reveal the relationships between the aforementioned variables. Two sets of relationships between the relevant sub-dimensions have been found to be statistically insignificant: 1) the relationship between the sub-dimensions "reduced personal accomplishment" and "continuance commitment," 2) the relationship between the sub-dimensions "depersonalization" and "normative commitment". Correlation coefficients in all other binary comparisons have been found out to be statistically significant. As a result, it has been demonstrated that there is a significant relationship between burnout and organizational commitment.
\end{abstract}

Keywords: Burnout, Organizational Commitment

\section{THEORETICAL PRINCIPLES}

\section{BURNOUT}

The concept of burnout was suggested by Herbert Freudenberger who wasworking as a psychoanalyst in a clinic in New York (Shepherd et al, 2011:397). However,the most widely accepted and used definition of burnout was made by Maslach whodescribed it as a multidimensional structure. According to author, burnout is a reaction tostress and job-related demands in the workplace, and involves emotional exhaustion, depersonalisation and personal accomplishment (Raiger, 2005: 72; Halbesleben and 
Demerouti, 2005: 208; Lee et al, 2010:405; Salmela-Aro et al, 2009:163; Oliveria et al,

2011:177). While emotional exhaustion refers to the depletion of emotional resources of

a person, depersonalisation means maintaining a remote and negative attitude towards

one's colleagues and disregarding them. Personal accomplishment feeling means considering oneself negative and inadequate in regard to job performance (Evers et al,

2004:132; Raiger, 2005:72).

\section{ORGANIZATIONAL COMMITMENT}

Organizational commitment serves as emotional and mental dependence to organization that on the basis of it high commitment person determines his/her identity in organization, cooperates in organization and enjoys due to organization membership (porter et al., 2004).

Morhead and Grifin know tow organizational commitments, identity sense and person dependence to organization. In their view commitment and loyalty affect on important behaviors such as replacing and absence and could commitment and loyalty, have more discipline in their job, stay in organization for a longer time and do more work organizational commitment dimensions from Allen and meyer model have emotional commitment, continuous commitment and normative commitment. Emotional commitment defines as dependence to an organization and determines identity that considers through organizational values acceptance and by tendency to stay in organization. Second dimension of Allen and Mayer organizational commitment is contineouse commitment that is on the basis of Biker investments. This theory is on this base that through the time, individual collects an asset in organization. In more experience, this asset is more and losing it has more cost. Such investments include organization especial skills obtain time that is not transferable.

Third dimension of organizational commitment is normative commitment that indicates one kind of responsibility to contineue cooperation. Responsible commitment has realized as a duty to support organization and its activities and refers to stay necessity in organization that individual think that to contineue activity and support organization is their responsibility (Allen, mayer, 2010).

\section{THE PURPOSE AND SIGNIFICANCE OF THE STUDY}

The main purpose of this study is to determine whether the levels of burnout ofemployees are related to their organizational commitments. Another purpose of the

present study is to reveal the relationships between the sub-dimensions of burnout and

the sub-dimensions of organization commitment. This is because; a clear understanding

and thus effective management of the relationships between the said two variables can

be achieved only in this way. The fewness of the number of studies where these two variables have beencovered and examined in the literature makes this study more significant. It is noteworthythat no such detailed study has been conducted on this subject in Turkey. This study willguide and be useful for both researchers and implementers in the future works.

\section{HYPOTHESES AND CONCEPTUAL MODEL DEVELOPMENT}

This study analyses burnout effect on organizational commitment of employees social security organization of west department of Mazandaran province. Studying model introduces in following beside research hypotheses.

H1: There is a negative relationship between burnout (and the relevant sub-dimensions) and organizational commitment. 
H2: The relationships between burnout (and the relevant subdimensions) and the sub-dimensions of organizational commitment vary.

H3: Demographic variables constitute a difference in terms of burnout.

H4: Demographic variables constitute a difference in terms of organizational commitment.

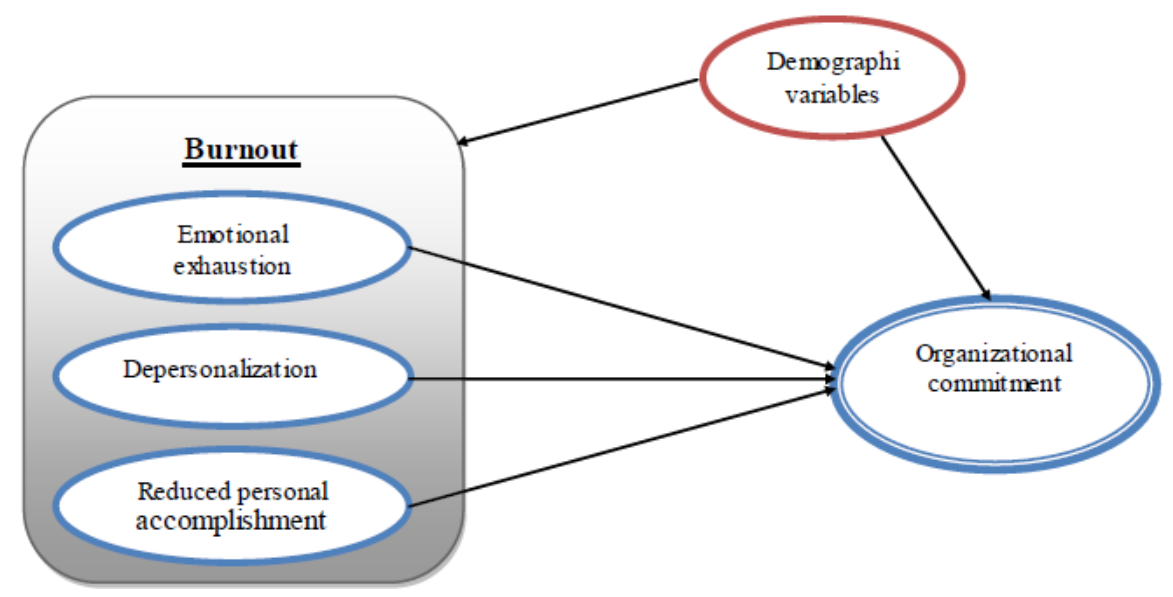

Figure 1- Research conceptual model, OZYER, 2014.

\section{METHODOLOGY}

Current research is according to its aim in practical researches type. Regarding to practical research aim that is to receive practical results, resolution finding for real issues and practical knowledge development is in a special area and method to do practical works, and this research knowing analyses burnout effect on organizational commitment of employees social security organization of west department of Mazandaran province. In data collection is descriptive, procedural. This method uses to know individuals views, believes and behavior and determines their correlation, or share and distinction according to obtained data from written or oral question and compares them. Using questionnaire, interview and observation are three methods to collect data in procedural studies (sakaran, 1387). Also in data certainity due to research on the basis of hypothesis and test hypotheses, research is certain. In this research, statistical community is all employees who are active in social security organization of west department of Mazandaran province and are $\mathbf{2 2 5}$ ones. Case mass using koocaran formula (random sampling) is $\mathbf{1 0 5}$ ones. In this research to study data collection has used two methods:

1- library method: subject literature, books, magazines, reports, theses, scientific researches and internet sites studied and necessary information collected in subject and research variables terms.

2- Field method to obtain needed information used questionnaire. This questionnaire descriptive has studied in content and face method and used masters and experts judgement. In this research has used chronbach alpha to determine stability and confirmatory factorial analysis. To calculate chronbach alpha used SPSS. Chronbach alpha was $\mathbf{0 . 9 2 4}$ for burnout, $\mathbf{0 . 9 3 6}$ organizational commitment. To analyse obtained results used method analysis technique. (structural equations modeling) using LISREL $8 / 5$

Table 1: Cronbach's alpha value of the research variables

\begin{tabular}{|c|c|}
\hline variable & Cronbach Alfa \\
\hline Burnout of job & 0.924 \\
\hline Organizational commitment & 0.936 \\
\hline
\end{tabular}


The Turkish Online Journal of Design, Art and Communication - TOJDAC August 2016 Special Edition

RESEARCH DATA AND FINDINGS ANALYSIS

Table 2,3 displays the results of Group Statistics

Table 2: Group Statistics Dimensionsof burnout

\begin{tabular}{|c|c|c|c|c|c|c|}
\hline Variables & $\mathrm{N}$ & Min & Max & Mean & S. D. & Std. Error Mean \\
\hline emotional exhaustion & 124 & 1.38 & 4.25 & 2.4844 & 0.78418 & 0.615 \\
\hline Depersonalization & 124 & 1.13 & 4.5 & 2.5239 & 0.78692 & 0.619 \\
\hline reduced personal accomplishment & 124 & 1 & 4.2 & 2.2734 & 0.76797 & 0.590 \\
\hline
\end{tabular}

Table 3: Group Statistics variable of organizational commitment

\begin{tabular}{|c|c|c|c|c|c|c|}
\hline Variables & $\mathrm{N}$ & Min & Max & Mean & S. D. & Std. Error Mean \\
\hline organizational commitment & 124 & 2.51 & 4.92 & 4.0921 & 0.34222 & 0.117 \\
\hline
\end{tabular}

Prior to the investigation of the relationship between burnout and organizationalcommitment, whether or not these variables display a normal distribution has been investigated. The results have showed that they display a normal distribution. Therefore, parametric analyses have been preferred. The Pearson correlation coefficient (a parametric test) has been calculated in order to reveal the relationships between the aforementioned variables. Table 4 displays the results of the correlation analyses between burnout and organizational commitment. The results demonstrate that hypotheses $1,2,3,4$ are correct.

Table 4: Correlations between burnout and organization commitment

\begin{tabular}{|c|c|c|c|}
\hline & & Burnout & organizational commitment \\
\hline \multirow{3}{*}{ Burnout } & Pearson Correlation & 1 & $-.821^{* *}$ \\
\hline & Sig. (2-tailed) & & .000 \\
\hline & $\mathrm{N}$ & 124 & 124 \\
\hline \multirow{3}{*}{$\begin{array}{c}\text { organizational } \\
\text { commitment }\end{array}$} & Pearson Correlation & $-.821^{* *}$ & 1 \\
\hline & Sig. (2-tailed) & .000 & \\
\hline & $\mathrm{N}$ & 124 & 124 \\
\hline
\end{tabular}

Table 5: Correlations between Dimensions of burnoutand organization commitment

\begin{tabular}{|c|c|}
\hline & organizational commitment \\
\hline emotional exhaustion & $-.777^{* *}$ \\
\hline Depersonalization & $-.765^{* *}$ \\
\hline reduced personal accomplishment & $-.726^{* *}$ \\
\hline
\end{tabular}

Table 6: One-Sample Statistics of organizational commitment

\begin{tabular}{|c|c|c|c|c|}
\hline & $\mathrm{N}$ & Mean & Std. Deviation & Std. Error Mean \\
\hline organizational commitment & 124 & 4.0921 & .34222 & .03073 \\
\hline
\end{tabular}

Table 7: One-Sample Test

\begin{tabular}{|c|c|c|c|c|c|c|}
\hline \multicolumn{1}{|c|}{} & \multicolumn{9}{|c|}{ Test Value $=3$} \\
\cline { 2 - 7 } & \multirow{2}{*}{$\mathrm{t}$} & $\mathrm{df}$ & Sig. & $\begin{array}{c}\text { Mean } \\
\text { Difference }\end{array}$ & $\begin{array}{c}95 \% \text { Confidence Interval of } \\
\text { the Difference }\end{array}$ \\
\cline { 5 - 8 } & & & & Lower & Upper \\
\hline organizational commitment & 35.536 & 123 & .000 & 1.09210 & 1.0313 & 1.1529 \\
\hline
\end{tabular}

Table 8: One-Sample Statistics ofburnout

\begin{tabular}{|c|c|c|c|c|}
\hline & $\mathrm{N}$ & Mean & Std. Deviation & Std. Error Mean \\
\hline burnout & 124 & 2.4272 & .51825 & .04654 \\
\hline
\end{tabular}

Submit Date: 11.06.2016, Acceptance Date: 23.07.2016, DOI NO: 10.7456/1060AGSE/065

Copyright $\odot$ The Turkish Online Journal of Design, Art and Communication 
Table 9: One-Sample Test

\begin{tabular}{|c|c|c|c|c|c|c|}
\hline & \multicolumn{6}{|c|}{ Test Value $=4$} \\
\hline & \multirow[t]{2}{*}{$\mathrm{t}$} & \multirow[t]{2}{*}{ Df } & \multirow[t]{2}{*}{ Sig. } & \multirow{2}{*}{$\begin{array}{c}\text { Mean } \\
\text { Difference }\end{array}$} & \multicolumn{2}{|c|}{$\begin{array}{c}\text { 95\% Confidence Interval of } \\
\text { the Difference }\end{array}$} \\
\hline & & & & & Lower & Upper \\
\hline burnout & $33 . \overline{7}$ & 123 & .000 & -1.57275 & $\begin{array}{c}- \\
1.6649\end{array}$ & -1.4806 \\
\hline
\end{tabular}

\section{DISCUSSION AND CONCLUSION}

The analyses reveal quite interesting and significant results. The first important result is the existence of a negative relationship between burnout and organizationalcommitment. When their definitions are taken into consideration, this is hardly surprising. The unique contributions of this study lie in the relationships between the subdimensions of organizational commitment and burnout. As a matter of fact, the present study demonstrates the differences observed in the relationships between the subdimensions of organizational commitment and burnout levels. What is most critical here is the relationship between burnout and continuance commitment. Whereas burnout is negatively related to organizational commitment, affective commitment, and normative commitment, it seems to have a positive relationship with continuance commitment. Burnout by definition is a negative variable whereas organizational commitment is again by definition a positive variable. A negative correlation between these two variables is therefore to be expected as normal. However, it seems that as the burnout levels of the employees rise, so do their continuance commitment levels. The truth that emerges out of this finding is that perhaps continuance commitment is a variable to be questioned. Whereas literature usually accepts continuance commitment as a sub-form of organizational commitment, this finding shows to us that the subject should be investigated to a greater depth. It will perhaps be necessary, as a result of future studies, to separate continuance commitment from organizational commitment and define it under a new label.

There seems to be a generally significant relationship between the age of the participants and their levels of burnout and organizational commitment. As can be seen from the tables found in the analysis section, increasing age usually means higher levels of burnout. The same is valid for the subdimensions of burnout. This in itself seems to be ma natural conclusion because all participants are engaged in social, interpersonal jobs. As a result, their levels of burnout will rise with age, and it will be more difficult for them to cope with burnout, which is a psychological state. The education levels of the participants have led to certain differences, too. The critical point of this finding is that whereas education level has no impact on levels of organizational commitment, with the exception of continuance commitment, it hascreated significant differences both in total burnout and in its subdimensions. It is evident that different studies on this subject will be necessary in the future. It is clear that studies which are to focus on the sub-dimensions of variables will be more beneficent. It is thought that studies to be carried out with more participants and in different sectors will make important contributions to both researchers and practitioners.

\section{REFERENCES}

Allen, N. J., Meyer, J. P. (1990). The Measurement and Antecedents of Affective, Continuance and Normative Commitment, Journal of Occupational Psychology, 63,1 - 18.

Allen, N. J., Meyer, J. P. (1996). Affective, Continuance and Normative Commitment tothe Organization: An Examination of Construct Validity, Journal of Vocational Behavior, 49, 252 - 276.

Allen, N. J., Grisaffe, D. B. (2001). Employee Commitment to the Organization and Human Customer Reactions. Mepping the Linkages, Human Resource Management Review, 11, 209 - 236. 
Andersen, I., Borritz, M..,Christensen, K. B., Finn Diderichsen, (2010). Changing Job- Related Burnout After Intervention-A Quasi-Experimental Study in Six Human Service Organizations. JOEM, 52(3), 318-323.

Ashil, N. J., Rod, M. (2011). Burnout Processes in Non-Clinical Health Service Encounters. Journal of Business Research, 64, 1116-1127.

Becker, H. S. (1960). Notes on the Concept of Commitment, American Journal of Sociaolgy, 97, 15 22.

Blau, G. J., Boal, K. B. (1989). Using Job Involvement and Organizational Commitment Interactively to Predict Turnover, Journal of Management, 15 (1), 115 - 127.

Borritz, M., Rugulies, R., Bjorner, J., B., Villadsen, E., Mikkelsen, O., A. and Kristensen, T., S. (2006). Burnout Among Employees in Human Service Work: Design and Bbaseline Findings of the PUMA study. Scandinavian Journal of Public Health, 34,49-58.

Brooks, D. M., Bradt, J., Eyre, L., Hunt, A., and Dileo, C., (2010). Creative Approaches for Reducing Burnout in Medical Personel. The Arts in Psychotherapy, 37, 255-263.

Boyas, J., Wind, L. H., and Kang, S. Y. (2012). Exploring the Relationship Between EmploymentBased Social Capital, Job Stress, Burnout, and Intent to Leave Among Child Protection Workers: An Age-Based Path Analysis Model. Children and Youth Services Review, 34, 50-62.

Buchanan, B. (1974). Building Organizational Commitment: The Socialization of Managers

Galek,K., Flannelly,K. J., Grene, P. B., and Kudler,T. (2011). Burnout, Secondary raumatic Stress, and Social Support. Pastoral Psychol, 60:633-649.

Ghorpade, J., Lackritz, J. and Singh, G. (2007). Burnout and Personality: Evidence From Academia. Journal of Career Assessment, 15(2), 240-256.

Gonza'lez-Roma, V., Schaufeli, B., W., Bakker, B., A. and Lloret, S.(2006). Burnout and Work Engagement: Independent Factors or Opposite Poles? Journal of Vocational Behavior, 68, 165-174.

Hackett, R. D., Bycio, P. and Hausdorf, P. (1994). Further Assessment of Meyer Allen's (1991) Three - Component Model of Organizational Commitment, Journal of Applied Psychology, 79, 15 - 24.

Hakanen J., J., Bakker, B., A. and Schaufeli, B., W. (2006). Burnout and Work Engagement Among Teachers. Journal of School Psychology, 43, 495-513.

Hakanen, J. J., Schaufeli,W. B., and Ahola, K. (2008). The Job Demands-Resources Model: A ThreeYear Cross-Lagged Study of Burnout, Depression, Commitment, and Work Engagement. Work \& Stress: An International Journal of Work, Health \&Organisations, 22(3), 224-241.

Law, W., D. (2010). A Measure of Burnout for Business Students. Journal Of Education For Business, 85, 195-202.

Lee, J., Puig, A., Kim, Y., Shin, H., Lee, J. and Lee, M., S. (2010). Academic Burnout Profiles in Korean Adolescents. Stress and Health, 26, 404-416.

Leiter, M. P., and Maslach, C. (1988). The Impact of Interpersonal Environment on Burnout and Organizational Commitment. Journal OfOrganızatlonal Behavior, 9, 297-308.

Marien, P., Auvert, L., Porras, J. and Michel, G. (2010). Burn Out and Craft Emergency.Injury Prevention, 16, A1-A289.

Marmaya, N.H., Zawawi, N., Hitam, M., and Jody, J.M. (2011). OrganızatıonalCommıtment and Job Burnout Among Employees in Mmalaysia. InternationalConference on Business and Economics Research,.1, 185-187).

Matin, H. Z., Kalali, N. S., and Anvari, M. R. A. (2012). Do Demographic Variables Moderate the Relationship Between Job Burnout and its Consequences. Iranian Journal of Management Studies, 5(1), 47-61.

Pason, S. (2009). Moving Up or Moving Out: New Job Demands, Ability to Cope and burnout AmongPereira, S. M., Fonseca, A. M., and Carvalho, A. S. (2012). Burnout in Palliative Care: A Systematic Review. Nursing Ethics, 18(3), 317-326.

Porter, L.W., Crampon, W.J. and Smith, F.J. (1976). Organizational Commitment andanagerial Turnover: A Longitudinal Study, Organizational Behavior and Human Performance, 15, 87 - 98. 
Porter, L.W., Steers, R.M., Mowday, R.T. and Boulian, P.V. (1974). Organizational commitment, Job Satisfaction and Turnover Among PsychiatricTechnicians,Journal of Applied Psychology, 59, 603 609.

Raiger, J. (2005). Applying a Cultural Lens to the Concept of Burnout. Journal of Transcultural Nursing, 16(1), 2005 71-76.

Randall, D.M. (1987). Commitment and the Organization: The Organization Man Revised.Academic Management Review, 12, 460 - 471.

Randall, D.M., Fedor, D.B. and Longnecker, C.O. (1990). The Behavioral Expression of Organizational Commitment, Journal of Vocational Behavior, 36, 210 - 224.

Rusbult, C.E. and Farrell, D. (1983). A Longitudinal Test of the Investment Model: TheImpact on Job Satisfaction, Job Commitment and Turnover of Variations in

Rewards, Costs, Alternatives and Investments, Journal of Applied Psychology, 68,429 - 438.

Salmela-Aro, K., Tolvanen. And A., Nurmi, J-E. (2009). Achievement Strategies During University Studies Predict Early Career Burnout and Engagement. Journal ofVocational Behavior, 75, 162-172.

Sane, M. A., Devin, F. H., Jafari, R., and Zohoorian, Z. (2012). Relationship Between Physical Activity and it's Components with Burnout in Academic Members of Daregaz Universities. Procedia - Social and Behavioral Sciences, 46, 4291 - 4294.

Tett, R.P. and Meyer, J.P. (1993). Job Satisfaction, Organizational Commitment, urniver Intention and Turnover: Path Analysis Based on Meta-Analytic Findings. PersonalPsychology, 46, 259 -291.

Tsai, M.T. and Huang, C.C. (2008). The Relationship Among Ethical Climate Types, Facets of Job Satisfaction and the Three Components of Organizational Commitment: AStudy of Nurses in Taiwan, Journal of Business Ethics, 80, $565-581$.

Vanderberge, C. and Tremblay, M. (2008). The Role of Pay Satisfaction and Organizational Commitment in Turnover Intentions: A Two - Sample Study, Journal of Business Psychology, 22, $275-286$.

Vitell, S.J. and Singhapakdi, A. (2008). The Role of Ethics Instutionalization in Influencing Organizational Commitment, Job Satisfaction and Esprit de Corps, Journal of Business Ethics, 81, $343-353$.

Wasti, A. (2003). Organizational Commitment, Turnover Intentions and the Influence of Cultural Values, Journal of Occupational Psychology, 76, 303 - 321. 